\title{
Family fortunes: the persisting grandparents effects in contemporary British society
}

DOI:

10.1016/j.ssresearch.2018.08.010

\section{Document Version}

Final published version

Link to publication record in Manchester Research Explorer

\section{Citation for published version (APA):}

Zhang, M., \& Li, Y. (2018). Family fortunes: the persisting grandparents effects in contemporary British society. Social Science Research. https://doi.org/10.1016/j.ssresearch.2018.08.010

\section{Published in:}

Social Science Research

\section{Citing this paper}

Please note that where the full-text provided on Manchester Research Explorer is the Author Accepted Manuscript or Proof version this may differ from the final Published version. If citing, it is advised that you check and use the publisher's definitive version.

\section{General rights}

Copyright and moral rights for the publications made accessible in the Research Explorer are retained by the authors and/or other copyright owners and it is a condition of accessing publications that users recognise and abide by the legal requirements associated with these rights.

\section{Takedown policy}

If you believe that this document breaches copyright please refer to the University of Manchester's Takedown Procedures [http://man.ac.uk/04Y6Bo] or contact uml.scholarlycommunications@manchester.ac.uk providing relevant details, so we can investigate your claim.

\section{OPEN ACCESS}




\title{
Family fortunes: The persisting grandparents' effects in contemporary British society
}

\author{
Min Zhang ${ }^{\mathrm{a}, *}$, Yaojun $\mathrm{Li}^{\mathrm{b}, \mathrm{c}, * *}$ \\ ${ }^{a}$ Institute for Social \& Economic Research, University of Essex, Wivenhoe Park, Colchester, Essex, CO4 3SQ, UK \\ ${ }^{\mathrm{b}}$ Institute for Empirical Social Science Research, Xi'an Jiaotong University, Xi'an, 710049, Shaanxi, China \\ ${ }^{\mathrm{c}}$ Department of Sociology and Cathie Marsh Institute for Social Research, The University of Manchester, Oxford Rd, Manchester, M13 9PL, UK
}

\section{A R T I C L E I N F O}

\section{Keywords:}

Grandparents' effects

Class aspiration

Educational and occupational attainment Self-employment

UK

\begin{abstract}
A B S T R A C T
This study examines grandparents' effects on grandchildren in contemporary British society. We begin with grandchildren's occupational aspiration in their adolescent years and move on to assess their educational and class attainment in adulthood. Using the British Household Panel Survey and the UK Household Longitudinal Study, we find persisting grandparental effects in all three domains even after controlling for parents' socio-economic-cultural resources and other demographic and contextual factors. In addition, we find that self-employed grandparents have a strong impact on grandsons' (albeit not on granddaughters') likelihood of engagement in selfemployment, a pattern that holds true even when parents are not self-employed. Our study shows that grandparents' class still affects grandchildren's life chances in contemporary UK society just as earlier research showed for mid-20th century Britain and that the effects are manifested at different stages of the life course, from occupational aspiration as teenagers to educational attainment as young adults to occupational destination as adults.
\end{abstract}

\section{Introduction}

Social inequalities rooted in family origin and other ascriptive factors are enduring concerns for social scientists and for wider society alike. Such inequalities undermine the principle of social justice and engender a negative impact on the moral and economic life of society. In the past few decades, many studies have been conducted to examine the patterns and trends of social inequalities such as those associated with intergenerational social mobility. Yet, partly due to the lack of multigenerational data, existing mobility research in the UK and other countries has mainly focused on the association between two generations, mostly between father's and son's class positions. Studies based on the two-generational approach tend to assume a relatively short range of social reproduction in that family socio-economic-cultural advantages and disadvantages will pass from parents to children, with grandparents having 'little effect' (Becker and Tomes, 1986: S28) or dissipating 'at a geometric rate' (Solon, 2018: 2). ${ }^{1}$

\footnotetext{
${ }^{*}$ Corresponding author. Institute for Social \& Economic Research, University of Essex, Wivenhoe Park, Colchester, Essex, CO4 3SQ, UK.

** Corresponding author. Institute for Empirical Social Science Research, Xi'an Jiaotong University, Xi'an, 710049, Shaanxi, China.

E-mail addresses: min.zhang@essex.ac.uk (M. Zhang), yaojun.li@manchester.ac.uk (Y. Li).

${ }^{1}$ The two-generational approach envisions a transmission process in which children's attainment is shaped by parents' socioeconomic resources in the same manner as the parents' resources are determined by the grandparental generation. For example, estimating a parents-child earnings autocorrelation of 0.4 would yield a grandparents-child autocorrelation at 0.16 and the great-grandparents-child autocorrelation at 0.064 (Solon, 2018: 2). Under this condition, 'the families whose members occupy these positions and receive the associated rewards are shuffled substantially from one generation to next' (Mare, 2011: 6).
} 
The limitation of the two-generational approach is that it does not seem to fit with our everyday observation. In an influential paper, Mare challenged the two-generational paradigm and argued that it is likely that we have overstated intergenerational mobility ... or, at the very least, have misunderstood the pathways through which it occurs' (Mare, 2011: 19-20). Furthermore, he suggested that studies related to social inequalities should be open to a multi-generational approach.

To begin with, we may note the differences between the two approaches. The social mobility based on the two-generational association follows the process of a first-order Markovian chain. According to this approach, grandparents convey their social advantages to parents who then pass the advantages on to their own children. In this process, no direct association is expected between grandparents and grandchildren as the association is mediated (absorbed) by parental effects. The three-generational approach, on the other hand, examines the process of how grandchildren are influenced by their grandparents' resources over and above the parental effects. Whereas the three-generational approach agrees with the idea that family advantages are passed on to the next generation, it also tests whether grandparental influences reach beyond and manifest themselves net of parental influences. To establish the net grandparents-grandchildren associations, the research design needs to capture all the important parental characteristics (without measurement error) that are affected by grandparents and that matter to grandchildren's attainments (Pfeffer, 2014).

As compared with a two-generational approach, a multi-generational approach takes a longer-term perspective of social reproduction and appreciates the possibility that grandchildren may well receive benefits, either tangible or intangible, from grandparents and other kin over and above their parents' socio-economic resources. To be sure, quite a few multigenerational studies have been conducted in the past few decades. While the findings are mixed, a majority of the studies have reported positive grandparental effects. Yet most of the studies are focused on the U.S. (Beck, 1983; Ferguson and Ready, 2011; Hertel and Groh-Samberg, 2014; Jæger, 2012; Loury, 2006; Knigge, 2016; Sharkey and Elwert, 2011; Warren and Hauser, 1997; Wightman and Danziger, 2014) or Western European countries (Bol and Kalmijn, 2016; Chan and Boliver, 2014; Deindl and Tieben, 2017; Erola and Moisio, 2006; Hertel and Groh-Samberg, 2014; Møllegaard and Jæger, 2015; Modin et al., 2012). In contrast, there are, to our knowledge, only two studies on contemporary Britain (Chan and Boliver, 2013; Moulton et al., 2017), a country which has long been held as emblematic of a 'sclerotic' class rigidity (Olsen, 1982: 86) and which is still diagnosed as having 'a deep social mobility problem' (Social Mobility Commission, 2016: iii). Another notable feature in the existing studies is that they tend to focus on a single outcome such as school completion or admission to higher education or access to professional-managerial salariat. In this paper, we conduct a three-generational analysis in contemporary UK society with a life-course perspective, focusing on grandparental effects on grandchildren starting from their occupational aspiration as teenagers and moving on to their educational attainment as young adults and furthermore to their occupational destination as adults. In so doing, we wish to provide new insight into how family origins of both parents and grandparents exercise their influences in the UK and whether there are clearly discernible grandparental effects net of parental influences on the key domains of grandchildren's socio-economic attainment. Variations in personal attainment across the life stages offer a great opportunity to develop our understanding of social reproduction over generations in Britain, a highly unequal society.

In the following, we shall first review the previous research on multigenerational inequalities and discuss possible mechanisms through which grandparental effects operate at the different life stages of grandchildren. After that, we describe our data and methods, followed by presentation of our findings. In the last section, we discuss the main findings.

\section{Research findings on three-generational mobility}

The present study will focus on aspirations, education and class attainment. But firstly, let us see what existing research has revealed on grandparents' effects. Grandparents may play a role on grandchildren's education as early as grandchildren's kindergarten age. Ferguson and Ready (2011) reported that college-educated grandparents in the US tend to have a net positive influence on grandchildren's mathematics and literacy skills when grandchildren entered kindergartens at the average age of 5.5. Similarly, Moulton et al. (2017) reported that, in the UK, grandchildren's class aspiration, even at an early age of seven, is directly affected by paternal grandmothers' social class. Whilst the sizes of the effects as shown in these studies are fairly small, one could argue that even the small differences at the early age could have a profound impact on children's academic performance and career choice in their later lives.

When grandchildren go to school, those with highly-educated grandparents are found to perform better in language and mathematical classes than do their peers with poorly educated grandparents, and findings of this kind have been reported in various social contexts such as the USA (Loury, 2006), Sweden (Modin et al., 2012; Hällsten and Pfeffer, 2017), and Australia (Hancock et al., 2016). Grandparents' educational effects are also found to vary with parents' education as shown in Taiwan (Chiang and Park, 2015), or with coresidence with grandchildren as shown in rural China (Zeng and Xie, 2014). In addition, grandparents' resources are found to affect grandchildren's educational choice. Møllegaard and Jæger (2015) showed that Danish grandchildren whose grandparents possessed high cultural capital were more likely to choose academically orientated track which may lead to university education.

At the later ages, grandchildren may benefit from grandparents' resources in seeking opportunities of college education. Loury (2006) showed that, after controlling for parents' education and family environment, grandfather's schooling has strong effects on grandsons' chance of attending college in the USA. In a cross-national study, Deindl and Tieben (2017) reported significant grandparental effects on grandchildren's access to tertiary education in Germany, Italy, Denmark, Czech Republic, Luxembourg and Israel although, interestingly, not in Sweden, the Netherlands, Belgium or Slovenia. For adult grandchildren, grandparents' resources are found to have an impact on their years of education in Chile (Celhay and Gallegos, 2015). Wightman and Danziger (2014) found a different pattern in the USA in that grandparental effects are particularly strong on grandchildren's college entry if grandchildren 
originated from low-income parents. Similarly, Jæger (2012) reported that in the USA grandparents have direct impacts on the education of grandchildren who had disadvantaged parents. Similar findings are reported for grandsons' class in Britain in 1911 (Long and Ferrie, 2018: 22).

After grandchildren have entered the labour market, grandparents' effects are found to persist in terms of grandchildren's occupational position (see Beck, 1983, for the USA; Chan and Boliver, 2013, for the UK; and Hertel and Groh-Samberg, 2014, for the USGerman comparison) and social status (see Dribe and Helgertz, 2016, for Sweden). These studies have all controlled for parental influences and therefore pertain to net effects.

There are also studies that have found no grandparental effects. In an early paper, Hodge (1966: 25) argued that after controlling for father's occupation, grandfather's occupation 'does not have any appreciable direct effect' on grandson's occupation. Later on, in an influential paper, Warren and Hauser (1997) used the data from the Wisconsin Longitudinal Study (WLS) and found that grandparents did not directly affect grandchildren's education or occupational status. Erola and Moisio (2006) also reported that after controlling for parents' class, grandchildren's class was barely affected by grandfather's social position in Finland. However, Chan and Boliver (2014) reanalysed their results and showed that the evidence Erola and Moisio (2006) presented did not support their major argument. Chan and Boliver further suggested that a net association between grandparents' class and grandsons' class did exist in Finland. More recently, Bol and Kalmijn (2016) randomly chose grandparents from either paternal or maternal side in the Netherlands and found that after taking into account parental characteristics, no direct effects of grandparents on grandchildren's educational qualifications persisted.

The overall evidence in three-generational mobility studies is in favour of the existence of grandparental effects but this is not conclusive. The lack of consistency may be explained by the differences in the geographical locations and time periods under investigation. The reproduction of inequalities over three generations may also operate in some contexts and during some time periods but not in others as Mare (2011) pointed out. In some locations, such as mid-twentieth century Wisconsin, the persistency of inequalities may be "unusually weak" (Mare, 2011: 16). The cross-national study by Deindl and Tieben (2017) that we discussed earlier suggests that welfare state provisions may play a role in determining the resource transfer from grandparents to grandchildren. Furthermore, the lack of consistency may be attributable to measurement differences of grandparents' and parents' characteristics and to statistical methods used. For example, Warren and Hauser (1997) and Jæger (2012) used the same data (Wisconsin Longitudinal Study) but reached different conclusion due to the different research designs. By incorporating the interaction between intermediate family environments and grandparental characteristics, Jæger (2012) found that grandparental effects exist only on grandchildren who had low socio-economic status parents. Methodological considerations aside, one might also say that the association between grandparents and grandchildren may operate at different life stages of grandchildren, a perspective which has not been well-researched using the same data sources to the best of our knowledge.

Still other studies have found that social advantages or disadvantages of family origins have even longer-lasting effects across at least four generations (Bertaux and Bertaux-Wiame, 1997; Clark and Cummings, 2015; Hällsten, 2014; Lindahl et al., 2014; Stuhler, 2012). Due to data limitation, we confine the present analysis to three-generational associations in the UK.

\section{Potential mechanisms of grandparental effects}

Whilst numerous studies have reported grandparents' effects on grandchildren's attainment net of parental influences, questions arise as to what kind of resources possessed by grandparents are transmitted to grandchildren and how effective they are in promoting grandchildren's educational and social advancement. One of the mechanisms identified posits a need-directed relationship (Silverstein and Marenco, 2001), which operates at different life stages of both grandparents and grandchildren.

Compared to the relationship between parents and children that is guided strongly by natural affection and social norms, grandparental support is generally not governed by legal and institutional obligations (Pruchno and Johnson, 1996). Such a lack of explicit and specific prescription surrounding the role of grandparent results in flexibility and heterogeneity in its practice and perception. Nevertheless, the traditional view of family as a source of support at any age persists (Kemp, 2004), and quite a few studies have, as we have seen above, shown that the expectation of assistance from grandparents does exist. Articulated in different forms, for both the old and the young generations, a taken-for-granted expectation of grandparental support appears to remain in the practice of familial relations, especially in situations where such support is needed and desired (Kemp, 2004; Griggs et al., 2010; Hagestad, 2006). Grandchildren, whether at young ages or in adulthood, also feel obliged to spend time with their grandparents and expect to receive support from them in the time of need (Hagestad, 2006). The closeness and supportiveness of the interaction between grandparents and grandchildren are generally valued and manifested across cultures.

Providing baby-sitting and childcare is a common way in which grandparents are directly involved in pre-teen grandchildren's life. Grandparents were the most commonly used childcare resources in the UK: 58 per cent of families had been helped by a grandparent with childcare in the previous year (Woodland et al., 2004). Seen from the perspective of British grandparents, 27 per cent of grandmothers and 19 per cent of grandfathers helped look after their grandchildren (Murphy and Grundy, 2003). Grandparents were considered the most satisfactory caregivers compared to other kinds of help (Meltzer, 1994). It is worth mentioning that a study carried out by Gray (2005) using the British Household Panel Study (BHPS), the same dataset as used in the present research, identified an increase in the provision of childcare by grandparents between 1991 and 2000. The childcare provided by grandparents certainly involves direct face-to-face interactions between grandparents and grandchildren, and also frees parents from pressures of looking after children, enabling parents to work longer hours and earn more money in the labour market (Gray, 2005; Wheelock and Jones, 2002).

As grandchildren reach school age, grandparental involvement may shift away from the provision of childcare and towards 
education-related activities. Griggs et al. (2010) suggested a trend towards a higher level of grandparental involvement in supporting their grandchildren's education in England and Wales than in the past. British grandparents are commonly engaged in activities including picking grandchildren from school, assisting them with homework, giving career advice (Griggs, et al, 2010), and visiting museums and art galleries (Beaumont and Sterry, 2005), especially when parents are unavailable. In the UK, approximately half of the families with school-aged children (at ages 8-14) use childcare provided by grandparents (Woodland et al., 2004). A positive relation between grandparents' active involvement and grandchildren's psychological well-being has also been found. These activities are not just educationally meaningful but also indicate a substantial amount of time and resource dedication, a highly valuable investment made by grandparents in their grandchildren's development. The grandparent-grandchild interactions also involve joyful companionship and confiding which may provide adolescent grandchildren with invaluable psychological support (Jamieson, 1998) and such interactions may facilitate the transfer of human capital and symbolic resources as well. A carpenter whose father was a professor may transmit different kinds of ideas to his son than another carpenter whose father was a cleaner. Factors like these may explain the frequent findings that grandchildren with socially advantaged grandparents tend to achieve better academic performance even when parental characteristics are taken into account.

Transfer of financial resources to grandchildren is another important channel for enhancing their educational attainment and improving their standard of living during their transition to adulthood and at the start of their career. In some ways, "money is something quantifiable that can be used to measure love" (Aldous, 1995: 115). British grandparents regularly provide their adolescent grandchildren with monetary assistance (Tan et al., 2010), particularly if grandparents are homeowners (Beach, 2013). In England, grandchildren received from grandparents a cumulative amount of approximately $£ 333.8$ million (excluding via Child Trust Funds) in 2010, which is equivalent to the tuition fee for more than 100,000 undergraduate placements (Beach, 2013). While older grandparents may be less physically capable of babysitting, they may have accumulated more financial resources to transfer to their grandchildren (Attias and Donfut et al., 2005; Beach, 2013; Silverstein and Marenco, 2001; Mueller and Elder, 2003). Using a nationally representative data of grandparents in the continental US, Silverstein and Marenco (2001) found that as grandparents grow old, they are more likely to provide their grandchildren with cash gifts, although they are less likely to engage in recreational activities with their grandchildren or serve as caregivers. Hoff (2007), using a longitudinal data source, found a trend of increasing financial transfers from grandparents to grandchildren in Germany.

Alternatively, grandchildren could benefit from bequests or inter-vivos transfers that their grandparents pass on to their parents. Individuals typically receive the bequest from their parents in their 50s. At this life stage they usually have achieved occupational maturity and their social positions are unlikely to be much changed by inheritance, but their children have strong economic needs since they have to pay tuition fees, housing costs, job searches, and many will also have their own babies to take care of. A recent British report found that the middle generation who received benefits from their elderly parents tend to pass on economic assistance to their own children (Royal London, 2017). In European countries, grandparents are also found to prefer to transfer financial resources to parents with children than to those without children (Albertini et al., 2007). Grandparents may also affect grandchildren in less direct ways. For example, grandchildren may benefit from a secure and stable environment, such as living in a catchment area with good schools, which grandparents contribute financially to securing (Ferguson and Ready, 2011; Hagestad, 2006).

One of the most important ways in which grandparents affect grandchildren's attainment is through transferring their knowledge, attitudes, values and family 'ethos' accruing from their socio-economic positions and life-long experiences (Portes et al., 2009). Such attitudes and values may shape grandchildren's aspiration and attainment in education and career as we shall find regarding entrepreneurism in Britain.

In addition, grandparents may function as a source of wisdom and information to adolescents when making important decisions, as a British study has shown (Griggs et al., 2010). Educational and occupational advantages accord grandparents authority to their grandchildren and therefore facilitate the transfer of information, attitudes and values that encourage the development of their descendants in academic and career areas. A U.S. study shows that whilst grandparents in all social positions consider their supports as being influential to the academic performance of their grandchildren, college graduates tend to be more convinced by the mentorship, advice and guidance offered by their well-educated grandparents (Crosnoe and Elder, 2002). King and Elder (1998) reported that in Iowa, USA, college-educated grandparents were more inclined to play a mentoring role, discuss the problems the grandchildren face and help them make more informed plans for the future, while grandparents with lower educational qualifications were more likely to develop 'friendship' ties with their grandchildren by maintaining frequent contacts and fostering close emotional bonds.

Grandparental effects may also operate as role models that affect grandchildren's educational and occupational aspirations (Denham and Smith, 1989). By referring to the appropriate role models, grandchildren are able to form a more informed assessment of the link between educational qualifications and labour market rewards. In contrast, the lack of such role models may hamper the individual's educational choices and earnings expectations. Loury (2006) argued that grandparents, together with other kin from extended families, may form a family network which may encourage or inhibit educational choices grandchildren make.

Grandparents' social positions may shape the reference frame guiding grandchildren's mobility decisions (Hertel and GrohSamberg, 2014). Family traditions that are known to the offspring play a crucial role in shaping their decision-making. Grandparents social positions as an important constituent of family tradition may instil in grandchildren a sense of belonging, a domain of expertise as 'family tradition' and affect their aspiration (Long and Ferrie, 2018). From a three-generational perspective, it may well explain the pattern of counter-mobility, a 'back to root' scenario where grandchildren from downwardly mobile families tend to strive to return to high status positions similar to their grandparents' (Hertel and Groh-Samberg, 2014). The study on three-generational mobility in Britain by Chan and Boliver (2013) shows that having advantaged grandparents is directly associated with grandchildren's upward mobility. On the other hand, those from upwardly mobile families may be more ready to reconcile themselves to their current 
position in the working class. This mechanism of grandparental influences tends to operate in a more or less similar way regardless of whether grandparents are alive or deceased (Pfeffer, 2014).

Grandchildren in Britain tend to experience a high level of multi-dimensional grandparental involvement (Tan et al., 2010). While grandparental influences are diverse in their functions, the influences may evolve as the life course stages of grandparents and grandchildren change (Arrondel and Masson, 2001; Dunifon and Bajracharya, 2012; Pruchno and Johnson, 1996). Grandparental influences, whether operating directly or indirectly, instrumentally or symbolically, are important drivers for grandchildren's educational and occupational successes.

\section{The present study}

As earlier noted, this paper aims to explore the grandparental effects on grandchildren's educational and occupational outcomes at the different life stages in Britain. We focus on the social positions that adolescent grandchildren aspire to attain, and the educational qualifications and class positions that adult grandchildren have attained. In the three domains of outcomes, we assess the grandparental roles net of parental characteristics.

As early as nine years of age, children can tell which jobs need more education, skills, and efforts, have higher incomes and status, and face greater risks (Gottfredson, 2002). Contrary to stereotypical views that young people predominantly wish to become celebrities, the majority of young people have fairly realistic and attainable ambitions (Kintrea et al., 2011).

Ambition plays a crucial role in young people's achievements (Croll, 2008). Cultivation of children's aspiration is one of the most important channels through which families support children to achieve desirable social positions. Disadvantaged parents and children may have high aspirations in education and career (Siraj-Blatchford, 2010; Kintrea et al., 2011), but are constrained in realising their ambitions than their more advantaged counterparts (Croll, 2008). Furthermore, disadvantaged families who have high expectations for children tend to have limited knowledge of how their children can fulfil the aspiration through education and employment (Kintrea et al., 2011). 'The distribution of ambitions and attainment varied with parental background in a way that reinforced occupational advantage and disadvantage' (Croll, 2008: 264). More importantly, they may not have the required resources in supporting their children in realising their dreams. Thus, children may adjust their aspirations in view of their family resources and try to form realistically attainable life goals (Goldthorpe, 2000). Here grandparental resources may play a crucial role although research findings are mixed as noted above (Chiang and Park, 2015; Jæger, 2012).

Very young children may not have a clear view of social stratification. Thus, Moulton and her colleagues (2015) found that, for their sample of seven-year olds, paternal grandmother's class had a rather small impact on grandchildren's class aspiration. To remedy this, we use information on class aspiration as held by grandchildren aged 10-15. By that age, adolescent grandchildren would have a more developed sense of the kind of jobs they would wish to have in their adult life. Education is an important investment in human capital and plays a crucial role in class destination. Better education leads to better opportunities for attaining more advantaged class positions in later life stages. The effects of family origins on educational attainment have been well examined (see Goldthorpe, 2016, for an overview) but the results are usually based on the two-generational approach. Following Mare's suggestion (2011) and to complement Chan and Boliver (2013) who used rather early data sources, we analyse the grandparental effects on grandchildren's educational attainment in contemporary British society. Chan and Boliver combined three British cohort surveys (1946, 1958 and 1970) and focused on class attainment and we wish to provide a more up-to-date analysis of grandchildren's educational and occupational attainment as adults as well as their class aspiration in adolescence using the most recent panel surveys (see below). In all the three domains, we ask whether grandparents would play an important role net of parents' socio-economic resources. Furthermore, as Britain is held as a country with entrenched class rigidity marked by a high level of class inheritance, particularly associated with the petty bourgeoisie (Goldthorpe and Jackson, 2007), we shall conduct a specific analysis in this regard, too.

\section{Data and methods}

We use the British Household Panel Survey (BHPS) and the UK Household Longitudinal Study (UKHLS) for the present analysis. The BHPS is an annual panel survey of a nationally representative sample that started in 1991, with 18 waves. The initial sample yielded 8167 addresses and identified 13,840 persons (Lynn, 2006). The BHPS collects information of all adult members (aged 16 or over) within the selected household in successive waves, and if the members of the original sample move out, all adult members of the new household are also interviewed. New entrants to the selected household also become eligible for interview. Children in the selected households are interviewed after they reach the age of 16. The selection of the original household sample was stratified by region and socio-demographic characteristics using Postcode Address File for Great Britain as the sampling framework. The sample is broadly representative of British since the 1990s. The UK Household Longitudinal Study (the UKHLS) that began in 2009, also known as Understanding Society, is a valuable survey that collects rich data annually based on a sample of 40,000 UK households. The UKHLS builds on the success of the BHPS and incorporates a sample from the BHPS from Wave 2 onwards. Using a similar approach of following household members to the BHPS, the UKHLS conducts interviews with adult members of selected households and follows the respondents in successive waves; in the case where the household member split out from the households, they would be followed and interviewed, together with other adult residents in the new households. The follow-up rules used by the BHPS and the UKHLS are designed to imitate the demographic processes of population reproduction such as birth and death, emigration, and cohabitation/ marriage formation and cessation, representing the evolving pattern of households and families in the UK. The BHPS and the UKHLS are pooled together to produce the current data set.

To delineate the three-generational relationships, we first identify grandparents by using the records on family origins as provided 
by the survey respondents who are classified as 'parents' in the family relationship. A three-generational lineage is identified when the grandparent information is available in a two-generational association between parents and children. The questions of 'Thinking back to when you were 14 years old, what job was your father/mother doing at that time' and 'Thinking about your father's/mother's educational qualifications, please look at this card and tell me which best describes the type of qualifications your father gained" were asked to every eligible household member and the responses that the members identified as parents provided would be used as occupational and educational information on grandparents. ${ }^{2}$ That is, while 'parents' and 'children' are the actual respondents in the BHPS or UKHLS, 'grandparents' are not survey respondents but exist only in the records on family backgrounds that 'parents' provided. For ease of presentation, respondents who were identified as 'child (ren)' (to the 'parents') in three-generational lineages would be referred to as 'grandchild (ren)'. This study faces the same limitation as most other studies using retrospective data on grandparental information. However, despite the recall bias, retrospective data are found to contain fairly reliable information on socioeconomic standing such as occupation and education (Pfeffer, 2014).

\subsection{Variables}

As the foregoing discussion has indicated, we have three outcome variables for the present analysis: class aspirations as adolescents, and educational and class destination as adults. For class aspiration, we use data from the youth self-completion from the UKHLS $^{3}$ where children aged 10-15 are invited to complete a self-completion youth questionnaire. Grandchildren's class aspirations are measured with their answers to the question 'What job would you like to do once you leave school or finish full-time education?' Grandchildren's responses are coded into the four-digit Standard Occupation Classification 2010 (SOC 2010). We derived a five-level National Statistics Socio-economic Classification (NS-SEC) scheme from the SOC 2010 according to the guidance provided by the Office for National Statistics (ONS, 2010): (1) the professional and managerial (salariat) class, (2) the intermediate class (routine nonmanual including clerical and service workers), (3) own-account workers (self-employed with or without employees excluding professionals), (4) lower supervisors and technicians, and (5) routine manual workers. The question related to class aspiration was asked in Waves 1, 3 and 5 of the UKHLS. We assume that as adolescent grandchildren grow older, they would develop a more realistic aspiration for class attainment. For this reason, the aspiration variable was derived from the most recent records available in the data. ${ }^{4}$ Grandchildren's destination class (for those over the age of 30, with a mean of 38) as well as that of parents and grandparents are coded in the same way. For parental and grandparental class, the dominance approach was used.

Grandchildren's education as adults (and similarly, parental education) is measured as a five-level variable: (1) degree (first degree or above), (2) sub-degree (including teaching, nursing, and other qualifications below degree), (3) higher secondary (A-level or equivalent), (4) lower secondary (GCSE or equivalent), and (5) low (primary or no formal qualifications). Grandchildren's education is measured by highest educational qualifications they have attained. The analytic sample is confined to grandchildren aged 25 or over (with a mean of 33) on the grounds that most people would have completed their education by this stage (Breen et al., 2009). Grandchildren's education is used as the outcome variable. Parental education is coded in the same way but using the dominance approach (Erikson, 1984) whereby the higher level of father's or mother's education is used as parental education. ${ }^{5}$ Grandparents' education is measured as a four-fold variable: (1) Degree (First degree or equivalent), (2) Further educational qualifications, (3) Some qualifications, and (4) No qualifications.

Parental wealth is measured by household monthly income (in log), house ownership (owner-occupied or rental) as well as house price. ${ }^{6}$ In addition to the main outcome and explanatory variables discussed above, we include a range of factors as control variables in our modelling exercises, including, where appropriate, gender, birth cohorts, regions, ethnicity, and survey sources. Ethnicity is differentiated between white British and ethnic minorities. This is admittedly a rather crude measure and a lot of specific research has shown marked ethno-generational differences in education and labour market outcomes in Britain (Lessard-Philipps and Li, 2017; Li and Heath, 2016, 2018; Li, 2018a b), but to include detailed ethno-generational classifications would result in very small sample sizes in a multigenerational analysis. The UK has marked regional differences in occupational opportunities and we coded four categories -

\footnotetext{
${ }^{2}$ The interview question of parents' education (hence grandparents' education for our current purposes) was asked only once, at wave 13, in the BHPS but in every wave of the UKHLS. This results in a large number of missing data on grandparental education in the BHPS. The interview question of grandparents' occupation was asked at wave 1 and wave 8-18 in the BHPS and every wave in the UKHLS.

${ }^{3}$ The related information on class aspiration is also available in the last three waves of the BHPS. However, the age range of respondents eligible to answer questions of class aspiration is between 16 and 20 many of whom are beyond the 'formative' stage of cognitive development of occupational aspiration. Furthermore, the sample size of grandchildren who had records on parents and grandparents in the BHPS is too small to use. Given these factors, we decided to use the UKHLS data for the analysis of class aspiration.

${ }^{4}$ Indicators of educational aspiration are also available in the Youth Survey of the UKHLS. The respondents were asked: 'Would you like to go on to do further full-time education at a college or university?' and between $93 \%$ and $95 \%$ answered yes in the three waves with little variation. While these aspirations are commendable, approximately only round half of them could realise the dreams. Given this, we decided to use class aspiration instead of educational aspiration.

${ }^{5}$ In the sample, $34 \%$ of the grandchildren had fathers with higher education, $25 \%$ had mothers with higher education, and $41 \%$ were born to families in which father had higher education than mother, 25 per cent were born to families in which mother had higher education than father, and 41 per cent had parents with the same level of education.

${ }^{6}$ House price is measured by a quartile scale using the question "how much did you pay for the house" with the missing data being treated as the 'unknown' category. House price is transformed into quartiles within the surveys. We also tested the current property values for robustness and found that our findings are robust to different measures of parental wealth.
} 
England, Wales, Scotland, and Northern Ireland - to be included in the models.

We use methods as appropriate for the tasks at hand in the analysis. As a grandparent could come from paternal or maternal side, we take a grandchild who has grandparental information available only from one side, either paternal or maternal, as one observation and a grandchild who has grandparental information on both sides as two observations. As the outcome variables are hierarchically ranked, we use ordinal logistic regression ${ }^{7}$ and treat all education and class variables as categorical measures. To correct for the intraclass (within the same family) correlation, we use household-based cluster robust standard errors in our analysis (Rogers, 1993). ${ }^{8}$

\section{Findings}

We first have a look at the contour of our three outcome variables: class aspiration as adolescents and educational and occupational attainment as adults. Table 1 shows the data. For ease of presentation, we label the class and education categories as levels, with Level 1 referring to the highest level, namely, salariat and degree, and so on. With regard to class aspirations as adolescents, we find that the young people are highly ambitious. Around two thirds (64 per cent) wish to be professionals and managers (salariat) when they grow up, a figure much higher than their actual attainment rate as adults (40 per cent, also shown in the table). This mismatch partly reflects the youthful optimism and partly results from the cultural norms, echoing what has been discovered in previous studies (Croll, 2008; Kintrea et al., 2011). In terms of education as adults, we find that a quarter of grandchildren have degrees.

As the distribution for class aspiration is highly skewed, we conducted logistic regression analysis. For the other two outcome variables (educational and occupational attainment as adults), the distributions are more balanced, and we conducted ordinal logistic regressions. ${ }^{9}$

Table 2 reports logistic regression results on class aspirations of grandchildren aged 10-15 (aspirations for professional/managerial salariat $=1$, for other positions $=0) .{ }^{10}$ Three models are constructed: Model 1 looks at the grandparental class, Model 2 adds parental class, and Model 3 further adds parental education and financial situation in terms of housing ownership, housing price, and monthly income (in log), whilst all three models control for gender, ethnicity and region. ${ }^{11}$ Before going to details, we note that only one of the control variables is significant, namely, that of ethnicity. As compared with their peers from ethnic minority backgrounds, whites appear much less aspirational, with odds for salariat rather than other occupations being less than half relative to the ethnic minorities. ${ }^{12}$ With regard to our main interest, Model 1 shows strong grandparental effects, and the coefficients have fairly clear gradients. For instance, grandchildren with salariat grandparents have markedly high aspirations, with odds being 67 per cent higher than those with working-class grandparents. In Model 2, the grandparental effects are somewhat reduced as a result of the parental class effects being taken into account. Grandchildren from salariat parental homes have, as expected, very high aspirations but it is still the case that those with grandparents in higher (salariat and intermediate) positions have, regardless of parents' class, significantly higher aspirations than do their peers with working-class grandparents. And even more importantly, basically the same pattern obtains when, as shown in Model 3, parental education and economic situation are taken into further account. It would be unsurprising to see high aspirations by young children from advantaged homes with highly educated parents occupying high class positions and living in owner-occupied housing, but the crucial point is that, even with all these factors taken into account, having salariat grandparents still matters for the adolescents' career aspirations ${ }^{13}$

\footnotetext{
${ }^{7}$ Brant tests suggest that the key models violate the parallel regression assumption. We are able to fit partial proportional odds models that do not violate the parallel regression assumption and the main conclusions remain the same.

${ }^{8}$ We tested whether the sample design that does not distinguish paternal and maternal lineages would affect our findings. We assigned a weighting factor, 0.5, to grandchildren who had information on both paternal and maternal grandparents and, 1.0, to those with information on either paternal or maternal grandparents. A comparison of the results using the different weights shows no major difference. Results are available on request. We are grateful to Professor Peter Lynn at Essex University for advice in this regard.

${ }^{9}$ While the distributions in the educational and occupational attainment as adults do not fully fit the proportionality assumption, we conducted tests using multinomial logistic regressions. The substantive results are essentially the same as those reported in the text. Furthermore, the BIC indexes favour the ordinal logistic regression method. In addition, we tried the partial proportional odds models (Williams, 2006) and the results are also similar to what is reported. The results of the alternative tests are available on request.

${ }^{10}$ We also conducted ordinal logistic regression analysis on the class aspirations for the young people. The patterns are very similar to the logistic regression results. The data are available on request.

${ }^{11}$ We also tried including age in all three models but found the age coefficients non-significant, and we tested using full government regions in the modelling tables and found the main patterns unchanged. We are grateful to a Reviewer for alerting us to this. Full details of using the government regions are available on request.

${ }^{12}$ It has been well documented that ethnical minorities in Britain tend to outperform the white British in terms of educational attainment (Li, 2010, 2018a; Strand, 2014; Lessard Phillips and Li., 2017) and that ethnicity minority parents hold higher expectations for their children than do white parents (Basit, 2012; Moulton et al., 2017; Strand and Winston, 2008). We tested the interactions between ethnicity and family backgrounds and found no significant interaction effects. This may be due to our simple classification of ethnicity. More refined ethnic classifications might reveal such differences.

${ }^{13}$ It is also noted here that, all things being equal, grandchildren with missing data on grandparents' education have significantly low aspiration. This is consistent with the finding that having missing records of grandparents' education is associated with social disadvantages. Lynn (2006) shows that respondents failing to attend follow-up BHPS interviews disproportionately include those at "age 16-24, never married, unemployed, no qualifications, not active in any organizations, resident in Inner London, West Midlands conurbation, Merseyside, local authority or housing
} 
Table 1

Distributions of grandchildren's class aspiration, and educational and occupational attainment.

Source: The British Household Panel Survey and the UK Household Longitudinal Study.

\begin{tabular}{llll}
\hline & Class aspiration as adolescents & Educational attainment as adults & Class destination as adults \\
\hline Level 1 & 64.0 & 25.4 & 39.9 \\
Level 2 & 12.1 & 7.5 & 15.1 \\
Level 3 & 7.8 & 26.8 & 9.7 \\
Level 4 & 5.1 & 26.7 & 8.0 \\
Level 5 & 11.0 & 13.6 & 27.4 \\
N & 6670 & 9404 & 5833 \\
\hline
\end{tabular}

Note: For ease of presentation, Levels 1-5 are used in the table to refer to the class and educational categories as specified in the text. Weighted analysis is used in this and the following tables.

Table 2

Logistic regression coefficients on grandchildren's aspirations for professional/managerial positions.

Source: The UK Household Longitudinal Study.

\begin{tabular}{|c|c|c|c|}
\hline & M1 & M2 & M3 \\
\hline \multicolumn{4}{|l|}{ Grandparental class } \\
\hline Salariat & $1.673^{* * * *}$ & $1.402^{* * *}$ & $1.253^{* *}$ \\
\hline Intermediate & $1.338^{* * *}$ & $1.222^{*}$ & 1.119 \\
\hline Small employers & $1.221^{*}$ & 1.192 & 1.143 \\
\hline Supervisor and technician & $1.246^{*}$ & 1.209 & 1.175 \\
\hline \multicolumn{4}{|l|}{ Grandparental education } \\
\hline University degree & 1.246 & 1.115 & 0.992 \\
\hline Some education & 0.987 & 0.941 & 0.894 \\
\hline Post-school qualification & 0.942 & 0.911 & 0.901 \\
\hline Missing & 0.842 & 0.848 & $0.828^{*}$ \\
\hline \multicolumn{4}{|l|}{ Parental class } \\
\hline Salariat & & $2.087^{* * * *}$ & $1.499^{* * * *}$ \\
\hline Intermediate & & 1.248 & 1.112 \\
\hline Small employers & & 0.866 & $0.771^{*}$ \\
\hline Supervisor and technician & & 1.245 & 1.171 \\
\hline \multicolumn{4}{|l|}{ Parental education } \\
\hline Degree & & & $1.686^{* * * *}$ \\
\hline Sub-degree & & & 1.051 \\
\hline Higher secondary & & & 1.103 \\
\hline Lower secondary & & & 0.891 \\
\hline \multicolumn{4}{|l|}{ Parents' economic situation } \\
\hline Monthly income (log) & & & 0.904 \\
\hline House price quartile: Bottom & & & 1.086 \\
\hline House price quartile: 2 nd & & & $1.294^{*}$ \\
\hline House price quartile: 3 rd & & & $1.434^{* *}$ \\
\hline House price quartile: Top & & & $1.446^{* *}$ \\
\hline House price quartile: Unknown & & & $1.943^{* *}$ \\
\hline \multicolumn{4}{|l|}{ Control variables } \\
\hline Female & 1.070 & 1.071 & 1.069 \\
\hline White & $0.427^{* * *}$ & $0.388^{* * * *}$ & $0.410^{* * *}$ \\
\hline Wales & 0.966 & 0.998 & 0.972 \\
\hline Scotland & 1.066 & 1.046 & 1.029 \\
\hline Northern Ireland & 0.881 & 0.835 & 0.811 \\
\hline Constant & $3.451^{* * * *}$ & $2.777^{* * * *}$ & 5.546 *** \\
\hline Pseudo $\mathrm{R}^{2}$ & $2.984^{* * * *}$ & $2.416^{* * *}$ & $4.757^{* *}$ \\
\hline $\mathrm{N}$ & 6670 & 6670 & 6670 \\
\hline
\end{tabular}

Note: Reference categories are routine manual workers for grandparental and parental class, primary or no formal qualifications for grandparental and parental education, no house ownership, male, and England. ${ }^{*} p<0.05,{ }^{* *} p<0.01,{ }^{* * *} p<0.001$.

Having looked at grandparents' role on grandchildren's class aspiration in their adolescence, we now turn to grandparents' class impacts on adult grandchildren's educational and occupational attainment based on ordinal logistic regression models. The data are shown in Tables 3 and 4 respectively, with the same layout as in Table 2 although with more control variables included, such as birth cohort and data source. As the data for the two tables are drawn from the pooled BHPS and UKHLS for the grandchildren who are now adults (for those aged over 25 for educational attainment and over 30 for class destination as noted earlier), differentiating and

(footnote continued)

association tenant and in the bottom 40\% of the income distribution" (Lynn, 2006, p.76). 
Table 3

Ordinal logistic regression on grandchildren's educational attainment.

Source: The British Household Panel Survey and the UK Household Longitudinal Study.

\begin{tabular}{|c|c|c|c|}
\hline & M1 & M2 & M3 \\
\hline \multicolumn{4}{|l|}{ Grandparental class } \\
\hline Salariat & $2.245^{* * * *}$ & $1.792^{* * *}$ & $1.411^{* * * *}$ \\
\hline Intermediate & $1.608^{* * *}$ & $1.307^{* * *}$ & 1.153 \\
\hline Small employers & $1.483^{* * * *}$ & $1.418^{* * * *}$ & $1.296^{* * * *}$ \\
\hline Supervisor and technician & $1.428^{* * * *}$ & $1.283^{* * *}$ & $1.207^{* *}$ \\
\hline \multicolumn{4}{|l|}{ Grandparental education } \\
\hline University degree & $2.186^{* * * *}$ & $1.795^{* * * *}$ & $1.454^{*}$ \\
\hline Some education & $1.328^{* * *}$ & $1.227^{* *}$ & 1.100 \\
\hline Post-school qualification & $1.401^{* * * *}$ & $1.248^{* *}$ & 1.119 \\
\hline Missing & $0.819^{* * * *}$ & $0.846^{* *}$ & 0.911 \\
\hline \multicolumn{4}{|l|}{ Parental class } \\
\hline Salariat & & $3.073^{* * *}$ & $1.503^{* * *}$ \\
\hline Intermediate & & $2.214^{* * *}$ & $1.456^{* * *}$ \\
\hline Small employers & & $1.279^{* *}$ & 0.953 \\
\hline Supervisor and technician & & $1.448^{* * *}$ & 1.181 \\
\hline \multicolumn{4}{|l|}{ Parental education } \\
\hline Degree & & & $3.830^{* * *}$ \\
\hline Sub-degree & & & $2.362^{* * *}$ \\
\hline Higher secondary & & & $1.851^{* * *}$ \\
\hline Lower secondary & & & $1.556^{* * *}$ \\
\hline \multicolumn{4}{|l|}{ Parents' economic } \\
\hline Monthly income (log) & & & $1.287^{* * *}$ \\
\hline House price quartile: Bottom & & & $1.610^{* * *}$ \\
\hline House price quartile: 2nd & & & $1.719^{* * * *}$ \\
\hline House price quartile: 3 rd & & & $1.775^{* * *}$ \\
\hline House price quartile: Top & & & $2.114^{* * *}$ \\
\hline House price quartile: Unknown & & & $2.087^{* * *}$ \\
\hline \multicolumn{4}{|l|}{ Control variables } \\
\hline $1970 \mathrm{~s}$ & $2.143^{* * *}$ & $2.066^{* * * *}$ & $1.879^{* * *}$ \\
\hline $1980 \mathrm{~s}$ & $2.011^{* * *}$ & $1.865^{* * *}$ & $1.542^{* * *}$ \\
\hline Female & $1.520^{* * * *}$ & $1.536^{* * *}$ & $1.616^{* * *}$ \\
\hline White & $0.432^{* * * *}$ & $0.367^{* * *}$ & $0.343^{* * * *}$ \\
\hline Wales & 0.842 & 0.941 & 0.897 \\
\hline Scotland & $1.344^{* * * *}$ & $1.365^{* * *}$ & $1.366^{* * * *}$ \\
\hline Northern Ireland & 1.151 & 1.228 & 1.183 \\
\hline UKHLS & $1.683^{* * *}$ & $1.814^{* * *}$ & $1.396^{* * *}$ \\
\hline Intercept 1 & $0.263^{* * *}$ & $0.358^{* * *}$ & $2.964^{* *}$ \\
\hline Intercept 2 & 1.180 & $1.698^{* * * *}$ & $15.132^{* * * *}$ \\
\hline Intercept 3 & $3.911^{* * * *}$ & $5.906^{* * * *}$ & $56.357^{* * * *}$ \\
\hline Intercept 4 & $5.800^{* * *}$ & $8.883^{* * *}$ & $86.662^{* * * *}$ \\
\hline Pseudo $\mathrm{R}^{2}$ & 0.047 & 0.066 & 0.091 \\
\hline $\mathrm{N}$ & 9398 & 9398 & 9398 \\
\hline
\end{tabular}

Note: Reference categories are routine manual workers for grandparental and parental class, primary or no formal qualifications for grandparental and parental education, no home ownership, born in the 1960s, male, ethnic minorities, England, and BHPS. ${ }^{*} p<0.05$, ${ }^{* *} p<0.01,{ }^{* * *} p<0.001$.

assessing the cohort and data source effects as covariates are important and we take these into due consideration.

Table 3 reports the results on grandchildren's educational attainment as adults. As with Table 2, we first give a brief note on covariates. As is clearly shown in the lower part of Table 3, there is significant improvement in educational attainment over the cohorts, which is also shown in the UKHLS over the BHPS data. Women and people of ethnic minority heritages are also found to fare better than men and white British in educational attainment, as do the Scots over the rest of the population.

With regard to grandparental effects, we find, in Model 1 of Table 3, that grandchildren of grandparents in higher classes and with better education have significantly higher chances of achieving higher (rather than lower) educational qualifications than those whose grandparents were in disadvantaged positions. For example, net of grandparents' education, grandchildren with salariat grandparents have an advantage of being 2.2 times as likely as those with manual working-class grandparents to obtain higher educational qualifications. Similarly, net of grandparents' class, the chances of grandchildren with university-educated grandparents attaining higher rather than lower education are also approximately 2.2 times as high as the chances of those whose grandparents had only primary (or no formal) education. As earlier noted, this model does not include the parental effects. In Models 2 and 3 , we progressively include more parental effects, with parental class in Model 2 and parental education and wealth in Model 3 . While the parental effects are clearly shown in Models 2 and 3, what is of key importance for present purposes is the fact that the effects of grandparental resources (class and education) remain highly significant net of parental influences with, for instance, an odds of 1.4 times as high for those with salariat grandparents, and the magnitude of this is similar to that of parental salariat class. Combining the results here with those from Table 2, we may well argue that grandparents do have a highly important role not only in terms of 
Table 4

Ordinal logistic regression on grandchildren's class attainment.

Source: The British Household Panel Survey and the UK Household Longitudinal Study.

\begin{tabular}{|c|c|c|c|}
\hline & M1 & M2 & M3 \\
\hline \multicolumn{4}{|l|}{ Grandparental class } \\
\hline Salariat & $1.778^{* * * *}$ & $1.455^{* * *}$ & $1.218^{*}$ \\
\hline Intermediate & $1.452^{* * *}$ & $1.236^{*}$ & 1.157 \\
\hline Small employers & $1.285^{* *}$ & $1.207^{*}$ & 1.112 \\
\hline Supervisor and technician & $1.390^{* * * *}$ & $1.259^{* *}$ & 1.159 \\
\hline \multicolumn{4}{|l|}{ Grandparental education } \\
\hline University degree & 1.542 & 1.272 & 1.156 \\
\hline Some education & $1.491^{* * *}$ & $1.407^{* * *}$ & $1.308^{* *}$ \\
\hline Post-school qualification & $1.416^{* *}$ & $1.252^{*}$ & 1.181 \\
\hline Missing & 0.925 & 0.973 & 1.006 \\
\hline \multicolumn{4}{|l|}{ Parental class } \\
\hline Salariat & & $2.654^{* * * *}$ & $1.724^{* * *}$ \\
\hline Intermediate & & $2.013^{* * *}$ & $1.504^{* * *}$ \\
\hline Small employers & & $1.386^{* *}$ & 1.151 \\
\hline Supervisor and technician & & $1.361^{*}$ & 1.245 \\
\hline \multicolumn{4}{|l|}{ Parental education } \\
\hline Degree & & & $1.670^{* * *}$ \\
\hline Sub-degree & & & $1.552^{* *}$ \\
\hline Higher secondary & & & $1.532^{* * *}$ \\
\hline Lower secondary & & & $1.506^{* * *}$ \\
\hline \multicolumn{4}{|l|}{ Parents' economic } \\
\hline Monthly income (log) & & & $1.476^{* * *}$ \\
\hline House price quartile: Bottom & & & 1.127 \\
\hline House price quartile: 2nd & & & $1.329^{*}$ \\
\hline House price quartile: 3 rd & & & $1.739^{* * *}$ \\
\hline House price quartile: Top & & & $1.665^{* * *}$ \\
\hline House price quartile: Unknown & & & 1.217 \\
\hline \multicolumn{4}{|l|}{ Control variables } \\
\hline $1970 \mathrm{~s}$ & $1.481^{* * * *}$ & $1.423^{* * *}$ & $1.213^{*}$ \\
\hline $1980 \mathrm{~s}$ & $1.640^{* * *}$ & $1.514^{* * *}$ & 1.212 \\
\hline Female & $1.374^{* * *}$ & $1.356^{* * *}$ & $1.383^{* * *}$ \\
\hline White & $0.634^{* * * *}$ & $0.566^{* * *}$ & $0.573^{* * * *}$ \\
\hline Wales & $0.726^{* *}$ & $0.776^{*}$ & $0.743^{*}$ \\
\hline Scotland & 0.914 & 0.929 & 0.921 \\
\hline Northern Ireland & $0.698^{* *}$ & $0.765^{*}$ & $0.760^{*}$ \\
\hline UKHLS & $0.764^{* *}$ & $0.798^{* *}$ & $0.663^{* * *}$ \\
\hline Intercept 1 & $0.447^{* * *}$ & $0.613^{* *}$ & $12.899^{* * * *}$ \\
\hline Intercept 2 & $0.673^{*}$ & 0.935 & $19.911^{* * * *}$ \\
\hline Intercept 3 & 1.029 & $1.451^{*}$ & $31.455^{* * *}$ \\
\hline Intercept 4 & $1.980^{* * *}$ & $2.852^{* * *}$ & $63.689^{* * * *}$ \\
\hline Pseudo $\mathrm{R}^{2}$ & 0.024 & 0.038 & 0.054 \\
\hline $\mathrm{N}$ & 4833 & 4833 & 4833 \\
\hline
\end{tabular}

Note: Reference categories are routine manual workers for grandparental and parental class, primary or no formal qualifications for parental education, no home ownership, born in the 1960s, male, ethnic minorities, England, and BHPS. ${ }^{*} p<0.05,{ }^{* *} p<0.01$, ${ }^{* * *} p<0.001$.

grandchildren's formation of occupational aspiration when they were teenagers, but also in terms of their actual educational attainment as adults.

Turning to grandparental effects on grandchildren's class destination (for those over the age of 30) as shown in Table 4, we observe essentially the same features as in Table 3. As has often been observed, the British occupational structure has experienced a continual upgrading with more room at the top (Erikson and Goldthorpe, 1992; Goldthorpe, 1987; Li and Devine, 2011; Li and Heath, 2016), and this is also clearly shown in our data in that the younger cohorts are more likely to gain advantaged social positions. Women have now caught up with men in gaining access to the salariat although they are still lagging behind men in top-level salariat positions (Heath, 2018). Women are also more likely than men to take intermediate positions and less likely to be found in lower supervisorial, technician or manual positions. The situation of ethnic minorities is in certain aspects similar to that of women: they are more likely to experience 'hyper-cyclical' unemployment but in class terms, those fortunate enough to get jobs are not markedly disadvantaged as compared with the majority group (Cheung and Heath, 2007). Owing to the uneven socio-economic development, people in Wales and Northern Ireland have lower class positions than their counterparts in England.

With regard to grandparental effects on grandchildren's class destination, data in Model 1 of Table 4 again show that grandparents' class position is positively and significantly associated with grandchildren's class attainment. The gradients are clear, with those having salariat grandparents being nearly twice as likely to attain advantaged and avoid disadvantaged class positions as those with working-class grandparents. The chances of grandchildren with educated grandparents attaining advantaged class are approximately 50 per cent greater than the chances of those with poorly educated grandparents. The incorporation of parental class 
reduces the strength of grandparental effects as can be expected; however, grandparental class and education continue to be significant predictors as shown in Model 2. Finally, in Model 3 with the effects of parental education and wealth both held constant, we still find grandparental effects significant and persisting, albeit weaker than in the preceding models and smaller in size than the parental effects in the social and educational domains. ${ }^{14}$

The preceding analyses have shown that grandparents' class does have a significant effect on grandchildren's life chances, ranging from class aspiration in the adolescent years to educational and occupational attainment in the adult life. In the remaining part of this analysis, we turn to a specific area, that of grandparental effects on grandchildren's likelihood of engaging in own-account occupations (self-employment). As Treiman (1970) states, access to the mainstream labour market, especially to more favourable professional and managerial positions, tends to rely on formal educational qualifications in modern industrial societies. Yet, as Erikson and Goldthorpe (1992) also note, there are some 'residual' occupational sectors where this kind of education-based meritocracy does not apply and where families have a special interest in passing their 'going concerns' to their offspring. This kind of transmission may refer to both material interests and family values: families in such circumstances may have a strong desire to carry on their businesses inter- and multi-generationally and they may also place a special attachment to independence and work autonomy. Children of smallemployed heritages are often expected to carry on their family business, more so for males than for females. Distinctive patterns of family inheritance within this class have been well documented in the two-generational mobility research (Bukodi and Goldthorpe, 2012; Devine and Li, 2013; Goldthorpe and Jackson, 2007; Li and Devine, 2011). An interesting question in this regard is whether people with self-employed grandparents are also more likely to follow in their grandparents' footsteps.

In Table 5, we show grandparents' influence on grandchildren's likelihood of being found in own-account (self-employed) positions. The data are based on logistic regression and are presented for male and female grandchildren respectively. In each part, two models are conducted: Model 1 with the main and control variables as used in Model 3 of Table 4, and Model 2 excluding selfemployed parents. The reason for this kind of set-up is to see whether grandparental self-employment would have a clear impact on grandchildren's propensity for self-employment in the presence, or even in the absence, of parental self-employment.

The data in Table 5 show some important features about self-employment in the UK. Firstly, with regard to contextual factors, we find that men (grandsons) in Wales and Northern Ireland are significantly more likely than their peers in England to take up selfemployment, echoing our previous analysis (Table 4) about the less availability of more advantaged jobs in the two countries. Yet, women in Wales are less likely than those in England to engage in self-employment, possibly due to their greater employment in the public sector. For men, ethnicity does not seem to make any notable difference with regard to self-employment; for women, however, the white British are markedly more likely to be found in such jobs. Self-employed workers tend to rely on local networks for their businesses (Li, 2015) and ethnic minority women seem to be less embedded in the local communities.

Focusing on our main concern, we find that when grandparents' and parents' class and other attributes are taken into account (Model 1), parents' self-employment status has a salient influence on both grandsons' and granddaughters' propensity for self-employment. Interestingly, we also find that, other things being equal, men (but not women) with self-employed grandparents are significantly more likely to be self-employed even when their fathers were employees (Model 2). This suggests a very powerful influence of occupational inheritance exercised by self-employed grandparents, which manifests itself not only over the next (parental) generation but across multiple generations.

\section{Discussion and conclusion}

This paper has sought to contribute to our understanding of grandparental effects on grandchildren's outcomes at the different life stages in contemporary UK society. The analysis shows that grandparental class is directly associated with grandchildren's life chances over their life courses over and above parental effects: in terms of class aspiration as teenagers (aged 10-15), of educational and occupational attainment in adulthood, and of the propensity for self-employment. With a large number of factors taken into account such as parental resources (class, education, and wealth) as well as demographic and geographic attributes, grandparental effects remain significant predictors for grandchildren's life chances and life choices.

Our findings are consistent with most existing studies in this area, especially studies on Britain such as Long and Ferrie (2018) concerning grandfather's effects over the period 1850-1911 using matched data from the censuses of population, and Chan and Boliver (2014) on grandfather's effects using three cohort studies (1946, 1958 and 1970). We extend the time scale to cover contemporary UK society. Furthermore, we provide a more comprehensive account by taking a life-course perspective. Among the many factors that might explain the persisting grandparental class effects, we would argue that increased life expectancy and accumulated resources among the grandparental generation (Hoff, 2015) are the main reasons. The fact that people now live longer lives means that grandparents could spend more time with and look after their offspring, making greater contributions towards their offspring's achievement, such as babysitting, picking up from school, giving advice, engaging in recreational and educational activities, or providing financial support (Silverstein and Marenco, 2001). Grandparents may also have human capital knowledge or symbolic

\footnotetext{
${ }^{14}$ We also tested other models with grandchildren's education as an explanatory variable on their class destination, and that for men and women separately, with all other variables in Model 3 of Table 4 unchanged. Grandchildren's education does play a pronounced role on their destination. For instance, other things being equal, as compared with those with only primary or no formal qualifications, men and women with degrees have an odds of 13 and 18 respectively in gaining access to more advantaged and in avoiding more disadvantaged positions. With all these factors taken into account, grandparental class effect loses significance, suggesting that grandparental advantages are chiefly mediated through grandchildren's education.
} 
Table 5

Logistic regression coefficients on grandchildren's chances of self-employment.

Source: The British Household Panel Survey and the UK Household Longitudinal Study.

\begin{tabular}{|c|c|c|c|c|}
\hline & \multicolumn{3}{|c|}{ Grandsons } & Granddaughters \\
\hline & M1 & M2 & M1 & M2 \\
\hline \multicolumn{5}{|l|}{ Grandparents' class } \\
\hline Salariat & 0.956 & 0.882 & 1.297 & 1.304 \\
\hline Intermediate & 0.674 & 0.668 & 0.924 & 1.123 \\
\hline Small employers & $1.717^{* *}$ & $1.762^{* *}$ & 1.523 & 1.590 \\
\hline Supervisor and technician & 1.097 & 1.148 & 1.017 & 1.130 \\
\hline \multicolumn{5}{|l|}{ Grandparental education } \\
\hline University degree & 1.562 & 1.717 & 1.087 & 0.912 \\
\hline Some education & 1.313 & 1.467 & 1.003 & 1.076 \\
\hline Post-school qualification & 1.044 & 0.725 & 0.521 & 0.455 \\
\hline Missing & 0.740 & 0.778 & 1.023 & 0.900 \\
\hline \multicolumn{5}{|l|}{ Parents' class } \\
\hline Salariat & $1.744^{*}$ & $2.105^{* *}$ & 2.023 & 1.959 \\
\hline Intermediate & 1.644 & $1.838^{*}$ & 1.518 & 1.461 \\
\hline Small employers & $3.594^{* * *}$ & & $2.400^{*}$ & \\
\hline Supervisor and technician & 0.938 & 0.976 & 0.582 & 0.596 \\
\hline \multicolumn{5}{|l|}{ Parents' education } \\
\hline Degree & $0.509^{*}$ & $0.327^{* *}$ & 0.403 & 0.466 \\
\hline Sub-degree & $0.455^{*}$ & $0.413^{*}$ & 1.349 & 1.498 \\
\hline Higher secondary & 0.669 & $0.493^{*}$ & 0.707 & 0.688 \\
\hline Lower secondary & 0.777 & 0.604 & 0.777 & 0.821 \\
\hline \multicolumn{5}{|l|}{ Parental wealth } \\
\hline Monthly income (log) & 0.933 & 0.871 & $0.564^{*}$ & $0.485^{* *}$ \\
\hline House price quartile: Bottom & 1.318 & 1.450 & 0.662 & 0.731 \\
\hline House price quartile: 2nd & 1.362 & 1.313 & 0.924 & 1.268 \\
\hline House price quartile: 3 rd & 1.170 & 1.425 & 1.249 & 1.426 \\
\hline House price quartile: Top & 1.230 & 1.057 & 0.930 & 1.117 \\
\hline House price quartile: Unknown & 1.689 & $2.084^{*}$ & 1.196 & 1.248 \\
\hline \multicolumn{5}{|l|}{ Control variables } \\
\hline 1970s & 1.030 & 1.105 & $0.524^{*}$ & 0.603 \\
\hline $1980 \mathrm{~s}$ & 0.721 & 0.878 & 0.527 & 0.540 \\
\hline White & 0.790 & 0.667 & $3.159^{*}$ & 2.752 \\
\hline Wales & $2.104^{* *}$ & $1.994^{* *}$ & $0.265^{*}$ & $0.089^{*}$ \\
\hline Scotland & 1.189 & 1.351 & 0.810 & 0.923 \\
\hline Northern Ireland & $1.996^{*}$ & $2.232^{*}$ & 0.724 & 0.915 \\
\hline UKHLS & 1.080 & 1.002 & 1.120 & 1.509 \\
\hline Constant & $0.159^{*}$ & 0.294 & 2.040 & 5.326 \\
\hline Pseudo $\mathrm{R}^{2}$ & 0.082 & 0.065 & 0.077 & 0.078 \\
\hline $\mathrm{N}$ & 2752 & 2428 & 2081 & 1839 \\
\hline
\end{tabular}

Note: Reference categories are routine manual workers for grandparental and parental class, primary or no formal qualifications for parental education, no home ownership, born in the 1960s, male, ethnic minorities, England, and BHPS, ${ }^{*} p<0.05,{ }^{* *} p<0.01,{ }^{* * *} p<0.001$.

influences on grandchildren's attitudes, values and practices as shown in our findings on entrepreneurism.

A key challenge in the study of multigenerational inequalities is the question of whether the grandparents-grandchild associations as often observed in quantitative empirical studies really represent causal influences of grandparents' resources or are just spurious features that might arise due to the failure to control for relevant parental characteristics. Given the numerous pathways through which parents may affect their children's achievement, one can easily speculate about unspecified or omitted variable biases (Mare, 2014). This argument can be particularly relevant when the data contain only a very limited number of indicators of parental resources and when the heritability of some resources is not directly estimable in quantitative research (Pfeffer, 2014; Stuhler, 2012). Whereas most studies on multigenerational influences control only for a single indicator of parents' social position, an advantage of the present analysis is its ability to take into account a wide range of parental characteristics and contextual factors, including parental class, education, household income, property ownership and house price, as well as geographic and demographic attributes. Our findings on grandparental effects are thus robust. That said, due to data limitation as true of almost all quantitative studies, this study could not include all the relevant parental resources as we would have desired to. However, we would believe that even with more data on parental resources, true causality would still be very hard, if ever possible, to establish in statistical analysis (Bechhofer and Paterson, 2000). As Tabachnick and Fidell (2007: 122) point out, 'Demonstration of causality is a logical and experimental, rather than statistical, problem.' Yet, as Mare (2014) states, even without claiming casual interference, statistical analysis on multigenerational inequality is valuable in its own right in that it can improve our understanding of social reproduction over generations. From this perspective, grandparental class could be viewed as an essential constituent of family resources that are causally linked to grandchildren's attainment. For example, we found that for grandchildren originating from homes located in similar class positions, those who had salariat grandparents would still have higher aspirations and make greater educational and occupational achievements 
than do their counterparts with working-class grandparents. In this sense, we would suggest that having salariat grandparents is one of the defining characteristics of family origin advantages.

To conclude, this paper has contributed to the literature by analysing grandparental effects in contemporary British society. This paper, to our knowledge, is the first systematic study of grandparental effects on occupational aspiration and educational and class attainment in contemporary Britain from a life-course perspective. Grandparents are shown to play an important role in shaping grandchildren's life chances over their life courses, from formulating higher aspirations in adolescent years to securing higher educational and class positions in adult life. The main conclusion of this research is that independent of parental characteristics, grandparents' social class does have significant impacts on shaping grandchildren's fortunes. The first-order Markovian chain does not fully represent social mobility in Britain; rather, family fortunes persist over generations as Mare (2011) states.

\section{Acknowledgement}

We are grateful to Anthony Heath, Wendy Olsen, Vikki Boliver, Wendy Bottero, Peter Lynn, and anonymous reviewers for their valuable comments on an earlier draft of this article. The authors benefited from resources and facilities provided by the Cathie Marsh Institute for Social Research, the University of Manchester. Zhang wishes to thank the University of Manchester for the generous scholarship for the $\mathrm{PhD}$ from which the present paper is a product. Li also wishes to thank the Institute for Empirical Social Science Research (IESSR), Xi'an Jiaotong University, China for providing facilities for conducting some of the work reported in this paper during his stay there as a visiting professor. The authors alone are responsible for any errors that remain in the paper.

\section{References}

Albertini, M., Kohli, M., Vogel, C., 2007. Intergenerational transfers of time and money in European families: common patterns-different regimes? J. Eur. Soc. Pol. 17 (4), 319-334.

Aldous, J., 1995. New views of grandparents in intergenerational context. J. Fam. Issues 16 (1), 104-122.

Arrondel, L., Masson, A., 2001. Family transfers involving three generations. Scand. J. Econ. 103 (3), $415-443$.

Attias-Donfut, C., Ogg, J., Wolff, F.C., 2005. European patterns of intergenerational financial and time transfers. Eur. J. Ageing 2 (3), 161-173.

Basit, T.N., 2012. My parents have stressed that since I was a kid': young minority ethnic British citizens and the phenomenon of aspirational capital. Educ. Citizen Soc. Justice 7 (2), 129-143.

Beach, B., 2013. Grandparental Generosity: Financial Transfers from Grandparents to Grandchildren. London: ILC-UK.

Beaumont, E., Sterry, P., 2005. A study of grandparents and grandchildren as visitors to museums and art galleries in the UK. Mus. Soc. 3 (3), 167-180.

Bechhofer, F., Paterson, L., 2000. Principles of Research Design in the Social Sciences. Routledge, London.

Beck, S.H., 1983. The role of other family members in intergenerational occupational mobility. Socio. Q. 24 (2), $273-285$.

Becker, G.S., Tomes, N., 1986. Human capital and the rise and fall of families. J. Lab. Econ. 4, S1-S39.

Bertaux, D., Bertaux-Wiame, I., 1997. Heritage and its lineage: a case history of transmission and social mobility over five generations. In: Bertaux, D., Thompson, P.R. (Eds.), Pathways to Social Class: a Qualitative Approach to Social Mobility. Transaction Publishers, New Jersey, pp. 62-97.

Bol, T., Kalmijn, M., 2016. Grandparents' resources and grandchildren's schooling: does grandparental involvement moderate the grandparent effect? Soc. Sci. Res. 55, $155-170$.

Breen, R., Luijkx, R., Müller, W., Pollak, R., 2009. Nonpersistent Inequality in Educational Attainment: Evidence from Eight European Countries. Am. J. Sociol. 114 (5), $1475-1521$.

Bukodi, E., Goldthorpe, J.H., 2012. Decomposing 'social origins': the effects of parents' class, status, and education on the educational attainment of their children. Eur. Socio Rev. 29 (5), 1024-1039.

Celhay, P., Gallegos, S., 2015. Persistence in the transmission of education: evidence across three generations for Chile. J. Hum. Dev. Capabilities 16 (3), $420-451$.

Chan, T.W., Boliver, V., 2013. The grandparents effect in social mobility: evidence from British birth cohort studies. Am. Socio. Rev. 78 (4), $662-678$.

Chan, T.W., Boliver, V., 2014. Social mobility over three generations in Finland: a critique. Eur. Socio Rev. 30 (1), $13-17$.

Cheung, S., Heath, A., 2007. Nice work if you can get it: ethnic penalties in Great Britain'. In: Heath, A., Cheung, S. (Eds.), Unequal Chances: Ethnic Minorities in Western Labour Markets. Oxford University Press, Oxford, pp. 505-548.

Chiang, Y.L., Park, H., 2015. Do grandparents matter? A multigenerational perspective on educational attainment in Taiwan. Soc. Sci. Res. 51, 163-173.

Clark, G., Cummins, N., 2015. Intergenerational wealth mobility in England, 1858-2012: surnames and social mobility. Econ. J. 125 (582), $61-85$.

Croll, P., 2008. Occupational choice, socio-economic status and educational attainment: a study of the occupational choices and destinations of young people in the British Household Panel Survey. Res. Pap. Educ. 23 (3), 243-268.

Crosnoe, R., Elder, G.H., 2002. Life course transitions, the generational stake, and grandparent-grandchild relationships. J. Marriage Fam. 64 (4), 1089-1096.

Deindl, C., Tieben, N., 2017. Resources of grandparents: educational outcomes across three generations in Europe and Israel. J. Marriage Fam. 79 (3), $769-783$.

Denham, T.E., Smith, C.W., 1989. The influence of grandparents on grandchildren: a review of the literature and resources. Fam. Relat. 345-350.

Devine, F., Li, Y., 2013. The changing relationship between origins, education and destinations in the 1990s and 2000s. Br. J. Sociol. Educ. 34 (5-6), 766-791.

Dribe, M., Helgertz, J., 2016. The lasting impact of grandfathers: class, occupational status, and earnings over three generations in Sweden 1815-2011. J. Econ. Hist. 76 (4), 969-1000.

Dunifon, R., Bajracharya, A., 2012. The role of grandparents in the lives of youth. J. Fam. Issues 33 (9), $1168-1194$.

Erikson, R., 1984. Social class of men, women and families. Sociology 18 (4), 500-514.

Erikson, R., Goldthorpe, J.H., 1992. The Constant Flux: a Study of Class Mobility in Industrial Societies. Oxford University Press, USA.

Erola, J., Moisio, P., 2006. Social mobility over three generations in Finland, 1950-2000. Eur. Socio Rev. 23 (2), $169-183$.

Ferguson, J.L., Ready, D.D., 2011. Expanding notions of social reproduction: grandparents' educational attainment and grandchildren's cognitive skills. Early Child. Res. Q. 26 (2), 216-226.

Goldthorpe, J., 1987. Social Mobility and Class Structure in Modern Britain. Clarendon Press, Oxford.

Goldthorpe, J.H., 2000. On Sociology: Numbers, Narratives, and the Integration of Research and Theory. Oxford University Press, Oxford, UK.

Goldthorpe, J.H., 2016. Social mobility in modern Britain: changing structure, constant process. J. Br. Acad. 41, 89-111.

Goldthorpe, J.H., Jackson, M., 2007. Intergenerational class mobility in contemporary Britain: political concerns and empirical findings. Br. J. Sociol. 58 (4), 525-546. Gottfredson, L.S., 2002. Gottfredson's theory of circumscription, compromise, and self-creation. Career Choice Dev. 4, 85-148.

Gray, A., 2005. The changing availability of grandparents as carers and its implications for childcare policy in the UK. J. Soc. Pol. 34 (4), $557-577$.

Griggs, J., Tan, J.P., Buchanan, A., Attar-Schwartz, S., Flouri, E., 2010. They've always been there for me': grandparental involvement and child well-being. Child. Soc. 24 (3), 200-214.

Hagestad, G.O., 2006. Transfers between grandparents and grandchildren: the importance of taking a three-generation perspective. Zeitschrift für Familienforschung 18 (3), 315-332.

Hällsten, M., 2014. Inequality across three and four generations in egalitarian Sweden: 1st and 2nd cousin correlations in socio-economic outcomes. Res. Soc. Stratif. 
Mobil. 35, 19-33.

Hällsten, M., Pfeffer, F.T., 2017. Grand advantage: family wealth and grandchildren's educational achievement in Sweden. Am. Socio. Rev. 82 (2), 328-360.

Hancock, K., Mitrou, F., Povey, J., Campbell, A., Zubrick, S.R., 2016. Three-generation Education Patterns Among Grandparents, Parents and Grandchildren: Evidence of Grandparent Effects from Australia. No. 2016-08.

Heath, A., 2018. Social Progress. Oxford University Press, forthcoming, Oxford.

Hertel, F.R., Groh-Samberg, O., 2014. Class mobility across three generations in the US and Germany. Res. Soc. Stratif. Mobil. 35, 35-52.

Hodge, R.W., 1966. Occupational mobility as a probability process. Demography 3 (1), 19-34.

Hoff, A., 2007. Patterns of intergenerational support in grandparent-grandchild and parent-child relationships in Germany. Ageing Soc. 275, $643-665$.

Hoff, A., 2015. Current and Future Challenges of Family Care in the UK: Future of an Ageing Population. Government Office for Science, London Retrieved from.

https://www.gov.uk/government/publications/future-of-ageing-family-care-in-the-uk.

Jæger, M.M., 2012. The extended family and children's educational success. Am. Socio. Rev. 77 (6), $903-922$.

Jamieson, L., 1998. Intimacy: Personal Relationships in Modern Societies. Polity, Cambridge.

Kemp, C.L., 2004. "Grand" expectations: the experiences of grandparents and adult grandchildren. Can. J. Sociol. 29 (4), $499-525$.

Kintrea, K., St Clair, R., Houston, M., 2011. The Influence of Parents, Places and Poverty on Educational Attitudes and Aspirations. Joseph Rowntree Foundation, York.

Knigge, A., 2016. Beyond the parental generation: the influence of grandfathers and great-grandfathers on status attainment. Demography 53 (4), $1219-1244$.

King, V., Elder Jr., G.H., 1998. Education and grandparenting roles. Res. Aging 20 (4), 450-474.

Lessard-Phillips, L., Li, Y., 2017. Social stratification of education by ethnic minority groups over generations in the UK. Soc. Incl. 51, 45-54.

Li, Y., 2010. The labour market situation of minority ethnic groups in Britain and the USA. EurAmerica: A J. Eur. Am. Stud. 402, 259-309.

Li, Y., 2015. The flow of soul: a sociological study of generosity in England and Wales (2001 - 2011). In: Li, Y. (Ed.), The Handbook of Research Methods and Applications on Social Capital. Edward Elgar Publishing, Cheltenham, pp. 40-59.

Li, Y., 2018a. Integration journey: the social mobility trajectory of ethnic minority groups in Britain. Soc. Incl. 6 (3). https://doi.org/10.17645/si.v6i3.1496.

Li, Y., 2018b. Against the odds? Educational attainment and labour market position of the second generation minority ethnic members in the UK'. Ethnicities. https:// doi.org/10.1177/1468796818777546.

Li, Y., Devine, F., 2011. Is social mobility really declining? Intergenerational class mobility in Britain in the 1990s and the 2000s. Socio. Res. Online. https://doi.org/ $10.5153 /$ sro. 2424.

Li, Y., Heath, A., 2016. Class matters: a study of minority and majority social mobility in Britain, 1982-2011. Am. J. Sociol. 1221, 162-200.

Li, Y., Heath, A., 2018. Persisting disadvantages: a study of labour market dynamics of ethnic unemployment and earnings in the UK (2009-2015), forthcoming. J. Ethnic Minor. Stud.

Lindahl, M., Palme, M., Sandgren-Massih, S., Sjögren, A., 2014. A test of the Becker-Tomes model of human capital transmission using microdata on four generations. J. Hum. Cap. 8 (1), 80-96.

Long, J., Ferrie, J., 2018. Grandfathers matter(ed): occupational mobility across three generations in the US and Britain, 1850-1911. Econ. J. https://doi.org/10.1111/ ecoj.12590, Accessed date: 2 July 2018.

Loury, L.D., 2006. All in the extended family: effects of grandparents, aunts, and uncles on educational attainment. Am. Econ. Rev. 96 (2), 275-278.

Lynn, P., 2006. Quality Profile: British Household Panel Survey-version 2.0: Waves 1 to 13: 1991-2003. ISER report, Essex.

Mare, R.D., 2011. A multigenerational view of inequality. Demography 48 (1), 1-23.

Mare, R.D., 2014. Multigenerational aspects of social stratification: issues for further research. Res. Soc. Stratif. Mobil. 35, 121-128.

Meltzer, H., 1994. Day Care Services for Young Children. Department of Health, HMSO, London.

Murphy, M., Grundy, E., 2003. Mothers with living children and children with living mothers: the role of fertility and mortality in the period 1911-2050. Popul. Trends 112, 36-44 Summer.

Modin, B., Erikson, R., Vågerö, D., 2012. Intergenerational continuity in school performance: do grandparents matter? Eur. Socio Rev. 29 (4), 858-870.

Møllegaard, S., Jæger, M.M., 2015. The effect of grandparents' economic, cultural, and social capital on grandchildren's educational success. Res. Soc. Stratif. Mobil. 42, 11-19.

Moulton, V., Flouri, E., Joshi, H., Sullivan, A., 2017. The influence of grandparents' social class on children's aspirations. Br. J. Sociol. Educ. 38 (4), $500-517$.

Mueller, M.M., Elder, G.H., 2003. Family contingencies across the generations: grandparent-grandchild relationships in holistic perspective. J. Marriage Fam. 65 (2), 404-417.

Olson, M., 1982. The Rise and Decline of Nations. Yale University Press, New Haven.

ONS, 2010. Volume 3 the National Statistics Socio-economic Classification: Rebased on the SOC2010 User Manual. Palgrave Macmillan, Hamsphire, UK.

Pfeffer, F.T., 2014. Multigenerational approaches to social mobility. A multifaceted research agenda. Res. Soc. Stratif. Mobil. 35, 1.

Portes, A., Fernandez-Kelly, P., Haller, W., 2009. The adaptation of the immigrant second generation: theoretical overview and recent evidence. J. Ethnic Migrat. Stud. 35 (7), 1077-1104.

Pruchno, R.A., Johnson, K.W., 1996. Research on grandparenting: review of current studies and future needs. Generations 20, 65-70.

Rogers, W., 1993. Regression standard errors in clustered samples. Stata technical bulletin 3 (13).

Royal London, 2017. In: Will Harassed 'baby Boomers' rescue Generation Rent? Royal London Policy Paper 12. London: Royal London Mutual Insurance Society Ltd Available at. https://www.royallondon.com/Documents/PDFs/2017/Policy\%20Paper\%2012\%20Will\%20harassed\%20baby\%20boomers\%20rescue \%20Generation\%20Rent.pdf/ (Accessed at 10 February 2018).

Sharkey, P., Elwert, F., 2011. The legacy of disadvantage: multigenerational neighborhood effects on cognitive ability. Am. J. Sociol. 116 (6), $1934-1981$.

Silverstein, M., Marenco, A., 2001. How Americans enact the grandparent role across the family life course. J. Fam. Issues 22 (4), 493-522.

Siraj-Blatchford, I., 2010. Learning in the home and at school: how working class children 'succeed against the odds'. Br. Educ. Res. J. 36 (3), $463-482$.

Solon, G., 2018. What do we know so far about multigenerational mobility?. Econ. J. https://doi.org/10.1111/ecoj.12495 , Accessed date: 2 July 2018.

Social Mobility Commission, 2016. State of the Nation 2016: Social Mobility in Great Britain. HMSO, London.

Stuhler, J., 2012. Mobility across multiple generations: The iterated regression fallacy. Discussion Paper Series (No. 7072), Forschungsinstitut zur Zukunft der Arbeit. Institute for the Study of Labor (IZA) Available at. https://www.econstor.eu/bitstream/10419/69484/1/733628060.pdf, Accessed date: 27 April 2017.

Strand, S., 2014. Ethnicity, gender, social class and achievement gaps at age 16: intersectionality and 'Getting it' for the white working class. Res. Pap. Educ. 29 (2), 131-171.

Strand, S., Winston, J., 2008. Educational aspirations in inner city schools. Educ. Stud. 34 (4), 249-267.

Tabachnick, B.G., Fidell, L.S., 2007. In: Using Multivariate Statistics, fifth ed. Allyn \& Bacon, Boston.

Tan, J.P., Buchanan, A., Flouri, E., Attar-Schwartz, S., Griggs, J., 2010. Filling the parenting gap? Grandparent involvement with UK adolescents. J. Fam. Issues 31 (7), 992-1015.

Treiman, D.J., 1970. Industrialization and social stratification. Socio. Inq. 402, 207-234.

Warren, J.R., Hauser, R.M., 1997. Social stratification across three generations: new evidence from the Wisconsin Longitudinal Study. Am. Socio. Rev. 561-572.

Wheelock, J., Jones, K., 2002. 'Grandparents are the next best thing': informal childcare for working parents in urban Britain. J. Soc. Pol. 31 (3), $441-463$.

Wightman, P., Danziger, S., 2014. Multi-generational income disadvantage and the educational attainment of young adults. Res. Soc. Stratif. Mobil. 35, 53-69.

Williams, R., 2006. Generalized ordered logit/partial proportional odds models for ordinal dependent variables. STATA J. 6 (1), 58.

Woodland, S., Miller, M., Tipping, S., 2004. Repeat Study of Parents' Demand for Childcare. Research Report RR vol. 348. Department for Education and Skills, Sheffield.

Zeng, Z., Xie, Y., 2014. The effects of grandparents on children's schooling: evidence from rural China. Demography 51 (2), 599-617.. 